\title{
Expression of GTPase-deficient Ras Inhibits Vasopressin Signaling in Cultured Cortical Collecting Duct Cells
}

Ramona Wong, Lynn Heasley, Lili Ao, and Tomas Berl

Department of Medicine, University of Colorado School of Medicine, Denver, Colorado 80262

\begin{abstract}
Cross-talk between signaling pathways is increasingly recognized as integral to cellular function. We investigated whether the mitogen-activated protein kinase (MAPK) pathway alters vasopressin (AVP) stimulation of protein kinase A (PKA) by specifically studying the role of Ras. Mouse cortical collecting duct cells (M-1) were transfected with a cDNA encoding oncogenic Ras. Transfection was confirmed by Western blot analysis and functionally by enhanced basal MAPK activity. When compared with basal MAPK activity of $26.4 \pm 6.6 \mathrm{pmol} / \mathrm{mg} / \mathrm{min}$ in controls, basal MAPK activity varied widely in Ras-transfected clones from 29.0 \pm 6.6 to $96.6 \pm 13.4 \mathrm{pmol} / \mathrm{mg} / \mathrm{min}$. Clones that functionally expressed activated Ras displayed complete abolition of AVP-stimulated PKA activity, whereas those that failed to express elevated basal MAPK activity showed intact AVPstimulated PKA. The correlation between expression of high basal MAPK activity and inhibition of AVP-induced PKA yielded a correlation coefficient of $-0.92(P=0.009)$. Exposure to $10 \mu \mathrm{M}$ forskolin or $1 \mu \mathrm{g} / \mathrm{ml}$ cholera toxin resulted in comparable activation of PKA in all clones. We found no correlation between PKC activity of the clones and PKA inhibition. To assess whether the observed effect was due to one known Ras target, cells were transfected with constitutively activated Raf. M-1 cells expressing activated Raf exhibited elevated MAPK activity. The Raf clones showed no impairment of AVP-stimulated PKA activity. We conclude that expression of activated Ras is inhibitory of AVP-induced PKA activation in the M-1 cortical collecting duct cell line at a site proximal to $G_{\alpha s}$ protein. The failure of $R$ af to influence AVP signaling indicates that the action of Ras is through a pathway independent of this Ras target. ( $J$. Clin. Invest. 1995. 96:597-601.) Key words: vasopressin • protein kinase $A \cdot$ mitogen-activated protein kinase $\cdot$ Raf
\end{abstract}

\section{Introduction}

Considerable experimental evidence has accumulated to suggest that many of the hormones and autacoids that inhibit vasopressin

Address correspondence to Dr. Tomas Berl, C281, University of Colorado School of Medicine, 4200 E 9th Avenue, Denver, CO 80262. Phone: 303-270-7204; FAX: 303-270-4852.

Received for publication 14 November 1994 and accepted in revised form 23 February 1995.

J. Clin. Invest.

(C) The American Society for Clinical Investigation, Inc. 0021-9738/95/07/0597/05 \$2.00

Volume 96, July 1995, 597-601
(AVP) ${ }^{1}$ action in the mammalian collecting duct involve stimulation of protein kinase C (PKC) (1). In this regard, many of the counterregulators of AVP action, such as prostaglandin $E_{2}$ (2), endothelin (3), cholinergic agents (4), and EGF (5), couple to phospholipase C. Also, direct activation of PKC itself inhibits AVP-stimulated adenylyl cyclase in cultured collecting duct cells (6). However, in many cell types (7), including the collecting duct (8), stimulation of PKC also results in the activation of mitogen-activated protein kinases (MAPK).

Furthermore, we have recently shown an inverse relationship between the MAPK-activating properties of EGF and its inhibition of AVP stimulation of cAMP formation (8). Thus it remained undefined whether the inhibition of cAMP generation by MAPK was dependent or independent of PKC. In this regard, it is interesting to note that cross-talk between the protein kinase A (PKA) pathway and growth factor-activated MAPK cascade has been recently reported. This is manifested by inhibition of MAPK activity by cAMP $(9,10)$ or PKA $(11)$ in adipocytes, fibroblasts, and smooth muscle cells. However, such an inhibitory pathway is not universally present, as such inhibition is not evident in PC12 cells (10). In view of our noted observation, it was attractive to consider the possibility that stimulation of the growth factor receptor by its attendant kinase cascade could in turn inhibit adenylyl cyclase activity. This study was undertaken to assess whether activation of the pathway alters hormonemediated stimulation of cAMP formation. More specifically, we examined whether Ras and Raf, two intermediary proteins in the cascade, exert an effect on the adenylyl cyclase pathway.

\section{Methods}

Cell culture. The M-1 immortalized mouse cortical collecting duct cell line was developed and kindly provided by Dr. Geza Fejes-Toth (Dartmouth Medical School, Hanover, NH) (12). These cells represent a mixture of both principal and intercalated cells (13). The cells were expanded and routinely grown in RPMI 1640 medium supplemented with $10 \%$ FCS, $10 \mathrm{mM}$ Hepes, $24 \mathrm{mM} \mathrm{NaHCO}, 100 \mathrm{U} / \mathrm{ml}$ penicillin, $100 \mu \mathrm{g} / \mathrm{ml}$ streptomycin, $5 \mu \mathrm{g} / \mathrm{ml}$ transferrin, and $1 \mu \mathrm{M}$ dexamethasone. In experiments requiring basolateral AVP stimulation of PKA, cells were seeded on $25-\mathrm{mm}$ diameter, $0.45-\mu \mathrm{m}$ pore Falcon cell culture inserts and grown to confluence.

Retrovirus-mediated gene transfections. The retroviral expression vector MV7 (14) in which the human T24 H-Ras cDNA (Gy 12 Va) had been inserted at the HindIII site was packaged into replicationdefective retrovirus in GP+E-86 cells (15). Similarly, a cDNA encoding a constitutively active Raf-1 molecule (BXB Raf) (16) was inserted into pLXSN (17) and packaged. Polybrene $(8 \mu \mathrm{g} / \mathrm{ml})$ was added to the retrovirus-containing medium from the GP+E-86 packaging cells and filtered before a 24-h incubation with subconfluent monolayers of M-1

1. Abbreviations used in this paper: AVP, vasopressin; MAPK, mitogenactivated protein kinase; MEK, map Erk kinase; Neo, neomycin resistance gene; PKA, PKC, protein kinases A and C; TPA, tetradecaroyl phorbol acetate. 
cells. The infected M-1 cells were then replated and selected for G418 resistance conferred by the neomycin ( $\mathrm{Neo}$ ) resistance gene encoded within pMV7 and pLXSN. Individual G418-resistant colonies were expanded and screened for expression of Ras and Raf by Western blotting.

Ras and Raf immunoblotting. For analysis of Ras expression, confluent dishes of the various M-1 clones were collected in $10 \mathrm{mM}$ Hepes (pH 7.4), $2 \mathrm{mM} \mathrm{MgCl}_{2}, 1 \mathrm{mM}$ EGTA, $2 \mu \mathrm{g} / \mathrm{ml}$ leupeptin, $2 \mu \mathrm{g} / \mathrm{ml}$ aprotinin and disrupted by brief (15-s pulse) sonication (Vibra Cell; Sonics and Materials, Danbury, CT). After a 5-min centrifugation $\left(2,000 \mathrm{~g}\right.$ at $\left.4^{\circ} \mathrm{C}\right)$ to pellet intact cells and nuclei, plasma membranes were collected by a 5-min centrifugation $\left(10,000 \mathrm{~g}\right.$ at $\left.4^{\circ} \mathrm{C}\right)$. Equal aliquots of membrane proteins were resolved on an SDS, $12 \%$ polyacrylamide gel. For analysis of BXB Raf expression, soluble extracts of transfected cells were prepared with MAPK lysis buffer ( see the following section ), and equal aliquots were separated on SDS, $10 \%$ polyacrylamide gels.

The resolved proteins were transferred to nitrocellulose fillers that were then blocked with $1 \%$ nonfat dry milk in Tris-buffered saline, $0.1 \%$ Tween 20 (TTBS). The filter was incubated for $16 \mathrm{~h}$ with polyclonal antisera to Ras (Upstate Biotechnology, Inc., Lake Placid, NY) or Raf-1 (Santa Cruz Biotechnology, Santa Cruz, CA). Bound antibodies were visualized with ${ }^{125} \mathrm{I}$-labeled protein A and autoradiography.

Assay of MAPK activity. M-1 cells were grown on 100-mm dishes to $50 \%$ confluence, incubated for 3-4 h in RPMI 1640 medium with $0.1 \% \mathrm{BSA}$, and exposed for $10 \mathrm{~min}$ to $100 \mathrm{nM}$ TPA or a comparable volume of diluent DMSO. Treatment was terminated with aspiration of media, and cells were lysed with $1 \mathrm{ml}$ of ice-cold MAPK lysis buffer (0.5\% Triton $\mathrm{X}-100,50 \mathrm{mM} \beta$-glycerophosphate [pH 7.2], $2 \mathrm{mM}$ $\mathrm{MgCl}_{2}, 0.1 \mathrm{mM}$ sodium orthovanadate, $1 \mathrm{mM}$ EGTA, $1 \mathrm{mM}$ DTT 5 $\mu \mathrm{g} / \mathrm{ml}$ leupeptin, $0.2 \mathrm{U} / \mathrm{ml}$ aprotinin ). Cells were collected with a rubber policeman, debris was removed by a 5-min centrifugation at 10,000 $\mathrm{g}$, and supernatant cell-free extracts were used in the MAPK assay.

Cell-free extracts were partially purified on DEAE Sephacel as previously described (8). Briefly, the extracts were adsorbed to $0.5-\mathrm{ml}$ DEAE Sephacel columns (Pharmacia LKB, Piscataway, NJ), washed with three $1-\mathrm{ml}$ aliquots of buffer ( $50 \mathrm{mM} \beta$-glycerophosphate $[\mathrm{pH}$ 7.2], $0.1 \mathrm{mM}$ sodium orthovanadate, $1 \mathrm{mM}$ DTT, $1 \mathrm{mM}$ EGTA), and eluted with $0.5 \mathrm{ml}$ of the same buffer containing $500 \mathrm{mM} \mathrm{NaCl} .20-\mu \mathrm{l}$ aliquots were incubated at $30^{\circ} \mathrm{C}$ for $10 \mathrm{~min}$ with $20-\mu \mathrm{l}$ aliquots of a mixture containing $50 \mathrm{mM} \beta$-glycerophosphate $(\mathrm{pH} 7.2), 0.1 \mathrm{mM}$ sodium orthovanadate, $1 \mathrm{mM} \mathrm{MgCl} 2,1 \mathrm{mM}$ EGTA, $0.1 \mathrm{mM}\left[\gamma_{-}{ }^{32} \mathrm{P}\right]$ ATP, and $0.2 \mathrm{mM}$ EGFR 662-681 peptide (RRELVEPLTPSGEAPNQALLR). Reactions were terminated by addition of $10 \mu \mathrm{l}$ of $25 \%$ (wt/ vol) TCA, and aliquots of $45 \mu \mathrm{l}$ were spotted on pieces of Whatman P-81 phosphocellulose (Whatman, Hillsboro, OR) and washed four times with $75 \mathrm{mM} \mathrm{H} \mathrm{PO}_{4}$. Phosphorylated substrate that was retained on the Whatman P-81 filters was quantified in a scintillation counter.

PKA assay. M-1 cells were grown on cell culture inserts to confluence. Cells were incubated for 3-4 h in RPMI 1640 medium with $0.1 \%$ BSA and then treated for $10 \mathrm{~min}$ by aspiration and replacement of the basolateral media alone with $1 \mathrm{nM}$ AVP, $10 \mu \mathrm{M}$ forskolin, or $1 \mu \mathrm{g} / \mathrm{ml}$ cholera toxin. Treatment was terminated by aspiration of media and lysis of cells with $0.5 \mathrm{ml}$ of iced cell lysis buffer $(0.5 \%$ Triton $\mathrm{X}-100$, $50 \mathrm{mM} \beta$-glycerophosphate $[\mathrm{pH} 7.2], 2 \mathrm{mM} \mathrm{MgCl}_{2}, 0.1 \mathrm{mM}$ sodium orthovanadate, $1 \mathrm{mM}$ EGTA, $1 \mathrm{mM}$ DTT, $5 \mathrm{mg} / \mathrm{ml}$ leupeptin, $0.2 \mathrm{U} /$ $\mathrm{ml}$ aprotinin, and $0.1 \mathrm{mM} 3$-isobutyl-1-methylxanthine). Cell-free lysate was collected as previously described.

Aliquots $(20 \mu \mathrm{l})$ of cell-free extracts were incubated at $30^{\circ} \mathrm{C}$ for 10 min with $20 \mu \mathrm{l}$ of a solution containing $50 \mathrm{mM} \beta$-glycerophosphate ( $\mathrm{pH} 7.2$ ), $0.1 \mathrm{mM}$ sodium orthovanadate, $1 \mathrm{mM} \mathrm{MgCl}_{2}, 1 \mathrm{mM}$ EGTA, $0.1 \mathrm{mM}\left[\gamma_{-}{ }^{32} \mathrm{P}\right]$ ATP $(2,000 \mathrm{cpm} / \mathrm{pmol})$, and $0.1 \mathrm{mM}$ Kemptide (LRRASLG) (Bachem, California, Torrance, CA). The activity of PKA was determined by the difference in $\left[\gamma^{32} \mathrm{P}\right] \mathrm{ATP}$ incorporated in the absence and presence of the specific PKA inhibitor IP-20 at $25 \mu \mathrm{g} / \mathrm{ml}$. Maximal activity was determined by incubation with $3 \mu \mathrm{M}$ cAMP. Activity ratios were calculated as a ratio of the basal PKA activity to the maximal PKA activity assayed in the presence of cAMP. The maximal PKA activity was not different in extracts from control cells or cells stimulated
A
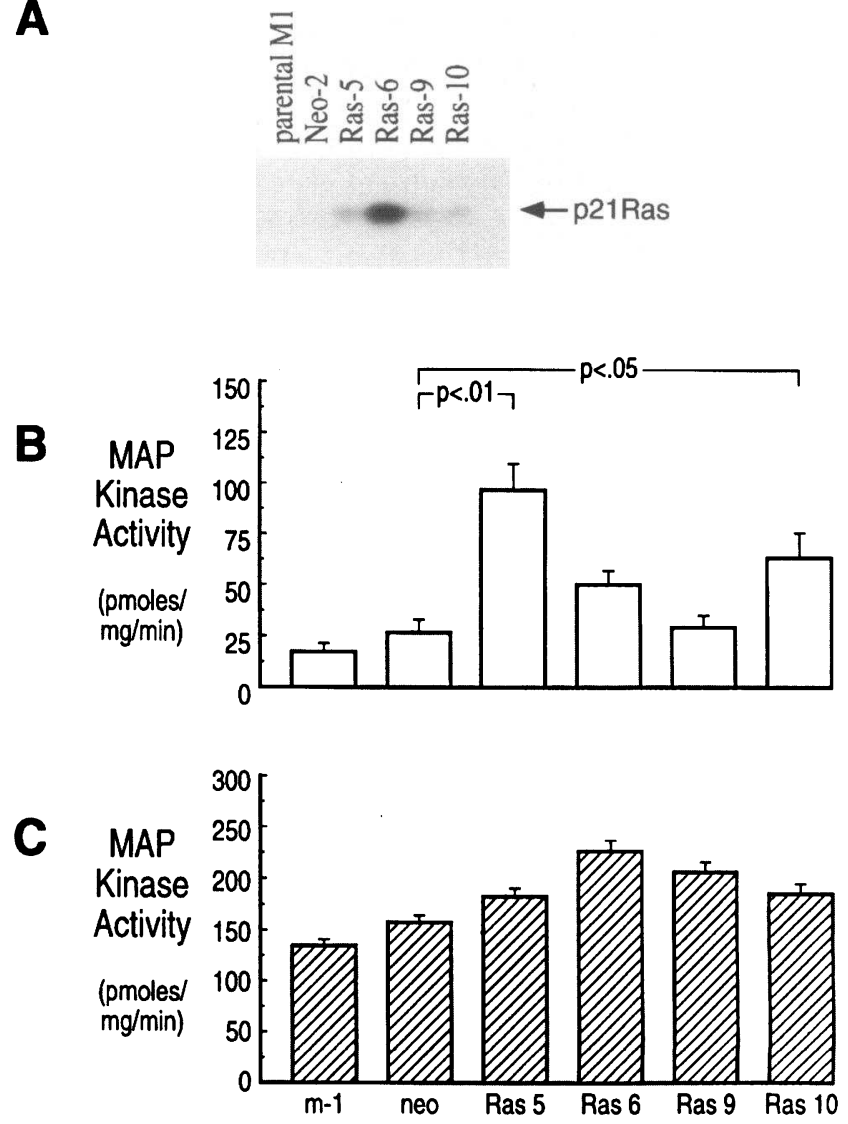

Figure 1. (A) Immunoblot showing the presence of Ras in the transfected clones and the absence in the parent M-1 cell and in controls transfected solely with a vector that confers neomycin resistance. $(B)$ Basal MAPK activity in the four clones and in control. $P<0.01$ vs controls; $P<0.05$ vs control. $(C)$ TPA $(100 \mathrm{nM})-$ stimulated MAPK activity in controls and Ras-transfected clones. There was no difference between the clones and controls.

with AVP, forskolin, or cholera toxin. Reactions were terminated, aliquots were spotted, and phosphorylated substrate was quantified via scintillation counter as previously described for MAPK assay.

Statistical analysis. Comparisons between two experimental settings were performed by paired $t$ test. When comparisons involved more than two groups, ANOVA was performed. Data are presented as means \pm SEM

\section{Results}

Evidence for transfection of $M-1$ cells. To assess whether the M-1 clones that were selected expressed the exogenous Ras protein, a Western blot of the plasma membrane preparation of each clone was performed using a specific anti-Ras antibody. As depicted in the top of Fig. $1 A$, each of the clones screened showed markedly elevated expression of Ras protein when compared with the parent (M-1) cell line or controls transfected only with vector lacking a cDNA insert (Neo control), which do not reveal the protein.

Assessment of functional expression. To assess whether the selected clones not only expressed the protein, but also possessed increased functional Ras activity, we examined the basal MAPK activity in the various clones. As seen in Fig. $1 B$, 


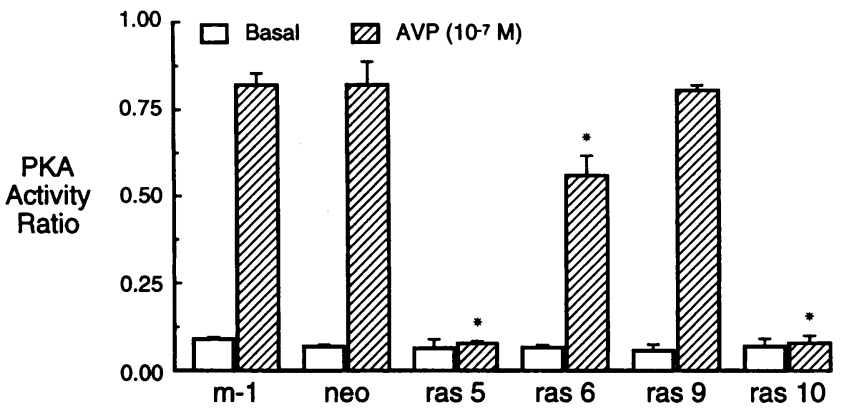

Figure 2. Basal and AVP-stimulated protein kinase activity ratio in M1 cells, Neo-transfected control, and the four selected Ras clones. Although basal activity was similar in all clones, the responses to AVP varied greatly $\left({ }^{*} P<0.01\right.$ compared with $\mathrm{M}-1$ or Neo control). Activity ratios were calculated by measuring PKA activity of a given aliquot of cell lysate in the absence and presence of $3 \mu \mathrm{M}$ cAMP and dividing the former by the latter. The activity ratio thereby shows the PKA activity induced by the given treatment relative to the maximal inducible PKA activity in that same aliquot.

despite the overexpression of Va 12 Ras protein in all clones, the functional expression was variable. The basal MAPK activity in these clones varied from $29.0 \pm 5.8 \mathrm{pmol} / \mathrm{mg} / \mathrm{min}$ (clone 9 ), not distinguishable from that of the parent cell line or the Neo control, to as high as $96.6 \pm 13.3 \mathrm{pmol} / \mathrm{mg} / \mathrm{min}$, an increment that was statistically significant $(P<.01)$, in clone 5 . Intermediate activity of MAPK was noted in clone $10(63.1 \pm 12.2$ $\mathrm{pmol} / \mathrm{mg} / \mathrm{min}, P<.05)$ and clone $6(49.9 \pm 6.6 \mathrm{pmol} / \mathrm{mg} / \mathrm{min})$, an increment that did not achieve statistical significance. As depicted in Fig. $1 C$, there was no significant difference in phorbol ester-stimulated MAPK between clones, suggesting that the cellular level of MAPK and its upstream activators was comparable in all clones and is not responsible for the differences observed in basal activity. It is also of note that we found no obvious correlation between the overexpression of Ras by Western blot and the increment in basal MAPK activity.

Effect of Ras activation on AVP-stimulated PKA. To assess whether the overexpression of Ras alters AVP-stimulated PKA activity, the latter was evaluated. Fig. 2 shows the basal and AVP-stimulated PKA activity ratio in the parent line, the Neo control, and the four selected clones for study. Whereas basal activities were minimal and comparable in all settings, the response to AVP varied. The M-1 and Neo control achieved ratios of $0.82 \pm 0.03$ and $0.83 \pm 0.06$, respectively. It is of note that a similar response to AVP was also seen in each of four other Neo control clones that were tested to ascertain the variability of the PKA response to AVP among clones. Clone 9, whose basal MAPK is low, had a response to AVP indistinguishable from the Neo controls. In contrast, clones expressing higher basal MAPK activity showed marked inhibition of AVP-stimulated PKA activity. Thus, clone 6, with intermediate expression, had a ratio of only $0.56 \pm 0.05(P<0.01)$, and even more marked was the essential abolition of response in clone 5 $(0.08 \pm 0.01), P<0.01$, and clone $10(0.08 \pm 0.02), P<0.01$, which expressed higher MAPK activity. In fact, when AVPinduced PKA activity was compared with basal MAPK, there was a highly significant inverse correlation of $n=-0.9207, P$ $=0.009$, as depicted in Fig. 3 .

Site of Ras-induced PKA inhibition. To assess the level by which Ras was inhibiting the response to AVP, we evaluated

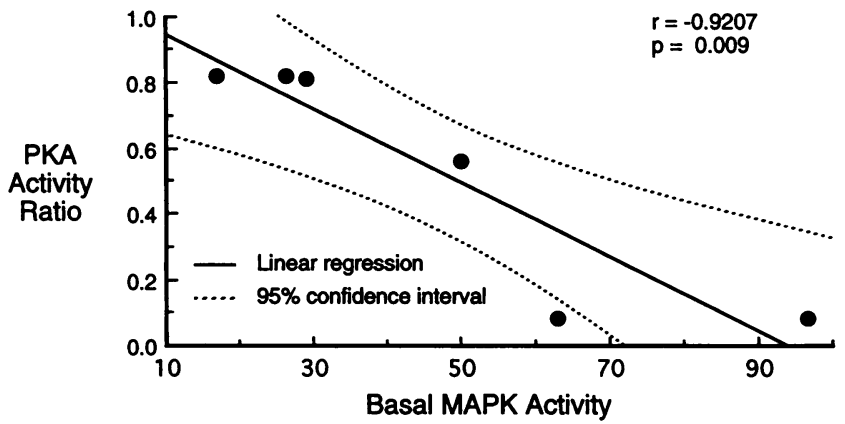

Figure 3. Correlation between basal MAPK activity and AVP-stimulated PKA in the studied clones. A marked negative correlation is observed.

the effects of $10 \mu \mathrm{M}$ forskolin and the effects of preincubation with $1 \mu \mathrm{g} / \mathrm{ml}$ cholera toxin. These results are shown in Table I. In contrast to the response to AVP, neither the direct stimulation of adenylyl cyclase (forskolin) nor the endogenous $\mathrm{G}_{\alpha s}$ (cholera toxin) was affected by Ras. These data thus suggest a mechanism acting upstream from $\mathrm{G}_{\alpha s}$, most likely at the AVP receptor.

Studies in cells overexpressing Raf. To test further our hypothesis that the Ras-activated MAPK pathway is responsible for the inhibition of AVP signaling in M-1 cells, we introduced a constitutively activated form of the Ras target Raf into cells. Fig. $4 \mathrm{~A}$ shows an immunoblot analysis in which the presence of BXB Raf is seen in the transfected clones, but not in the Neo control. As depicted in Fig. $4 B$, all three of the Raf clones displayed enhanced basal MAPK activity, indicating functional expression of the Raf construct. However, in contrast to our observation with the Ras-transfected clones, all of the Raf clones, despite exhibiting high basal MAPK, had intact responses to AVP that did not differ from those of the Neo control (Fig. $4 C$ ).

\section{Discussion}

It is now evident that cellular signaling involves an increasingly complex network of stimulatory and inhibitory pathways. These experiments were undertaken in an effort to define further the mechanisms of AVP resistance observed both functionally (5) and biochemically (6) in response to agents such as EGF that exert their effects by tyrosine kinase receptors. In renal collecting duct cells, EGF stimulates not only the cellular pathways leading to activation of MAPK, but also phospholipase C (18).

Table I. Basal, Forskolin-, and Cholera Toxin-Stimulated PKA Activity Ratio in M-1, Neo-Resistant Control, and Ras-transfected Clones

\begin{tabular}{lccccrr}
\hline \multicolumn{1}{c}{ Clone } & Basal & $n$ & $\begin{array}{c}\text { Forskolin } \\
(100 \mu \mathrm{M})\end{array}$ & $n$ & \multicolumn{1}{c}{$\begin{array}{c}\text { Cholera toxin } \\
(1 \mu \mathrm{g} / \mathrm{ml})\end{array}$} & $n$ \\
\hline M-1 & $0.09 \pm 0.01$ & 4 & $0.62 \pm 0.06$ & 3 & $1.0 \pm 0.06$ & 3 \\
Neo control & $0.07 \pm 0.01$ & 4 & $0.73 \pm 0.02$ & 4 & $0.96 \pm 0.02$ & 3 \\
Ras 5 & $0.07 \pm 0.02$ & 4 & $0.70 \pm 0.05$ & 4 & $1.0 \pm 0.11$ & 3 \\
Ras 6 & $0.07 \pm 0.01$ & 4 & $0.68 \pm 0.05$ & 4 & $1.1 \pm 0.05$ & 3 \\
Ras 9 & $0.06 \pm 0.02$ & 3 & $0.64 \pm 0.05$ & 3 & $0.97 \pm 0.04$ & 3 \\
Ras 10 & $0.07 \pm 0.02$ & 3 & $0.77 \pm 0.06$ & 3 & $1.0 \pm 0.06$ & 3 \\
& & & & & & \\
\hline
\end{tabular}


Since stimulation of PKC itself increases MAPK activity in these cells (8), it seems entirely possible that a component of this pathway is involved in the inhibitory effect. This possibility was further supported by our recent observation demonstrating a close correlation between the stimulation of MAPK with either EGF or carbachol and the agents' inhibition of AVP-stimulated cAMP generation (8). In the current study, we used a molecular approach to stimulate specifically the growth receptor-activated protein kinase cascades. To this end, we transfected a cDNA encoding, a GTPase-deficient Ras polypeptide into M-1 cortical collecting duct cells, thereby overexpressing this protein, which is a proximal regulator of the MAPK cascade (19-21).

The selected clones overexpressed the protein of interest as assessed by immunoblot analysis (Fig. 1). The absence of visible protein in the M-1 parental cell and the Neo control does not bespeak of the absence of Ras in such cells. In fact, we have found that even cells whose Ras activity is increased by EGF and PDGF show no visible protein on immunoblots, unlike transfectants that hyperexpress the protein (Nemenoff, R., personal communication). Thus, the immunoblot serves primarily as a screening devise for successful transfection and protein expression. Immunoblot also failed to predict the functional state of the cells as assessed by enhanced basal MAPK activity. Such functional expression was variable among clones, but was consistently reproducible in any given clone. The variability in turn provided a tool in the assessment of the role of this pathway in AVP-stimulated PKA stimulation. Whereas all of the clones transfected only with the neomycin resistance gene uniformly responded to AVP by stimulating PKA, the response of the Rastransfected clones seemed highly predictable from its degree of MAPK activation. We thus noted a highly significant $(P$ $=0.009)$ inverse relationship $(r=-0.9)$ between basal MAPK activity and AVP-stimulated PKA. It must be noted that though clone 10 had a marked suppression of the effect of AVP, clone 6 , with only somewhat lower basal MAP kinase activity, still had a substantial PKA response. It is thus possible that there is a critical threshold of Ras activity expression beyond which the effect of AVP is fully inhibited. It is also of interest that we found no correlation between the clone's basal PKC activity and the AVP stimulation of PKA $(r=-0.5, P=0.29$; data not shown).

We also undertook experiments to delineate the site of Ras inhibition. As the responses to both forskolin and cholera toxin were unperturbed, the catalytic unit of cyclase and the coupling $\mathrm{G}$ protein are unlikely targets. Thus the effect is most likely at the level of the AVP receptor. It is clear that protein kinase cascades target specific transcription factors and may thus act by decreasing the transcription of the AVP receptor. Alternatively, Ras or a protein distal to it could alter the internalization cycle of the receptor, thereby decreasing its availability to the plasma membrane.

The data we have described, in addition to lending support to the contention that a component of growth factor receptoractivated protein kinase cascade is involved in inhibition of AVP action, describe a novel inhibitory effect of Ras or a protein distal to it on AVP-stimulated adenylyl cyclase. In this regard, it is of interest to note that cAMP inhibits EGF (9), insulin (10), and PDGF (11) activation of MAPK. However, in collecting duct M-1 cells, such an inhibitory pathway is not operant. Specifically, in these cells we found that EGF stimulation of MAPK is unaltered in the presence of exogenous cAMP, by the addition of forskolin, or in transfectants with a constitu-
A
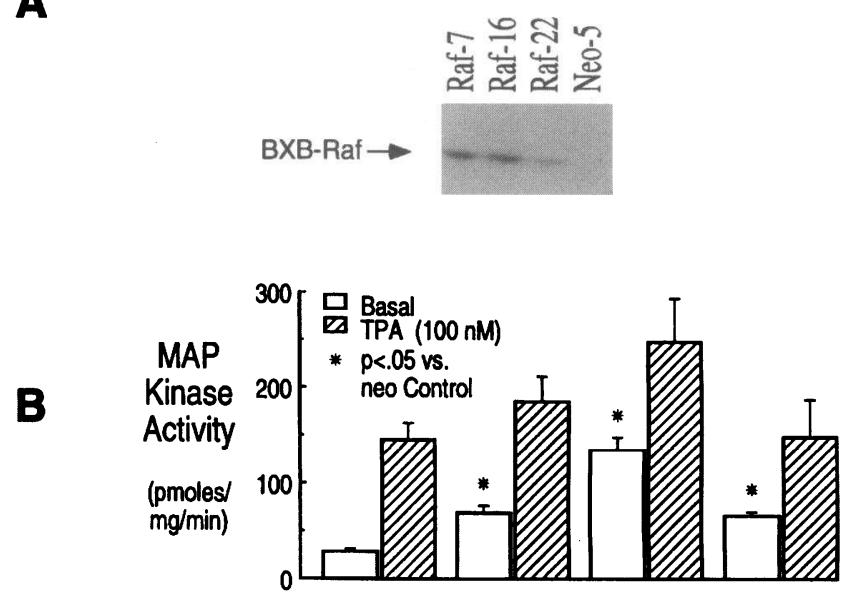

C

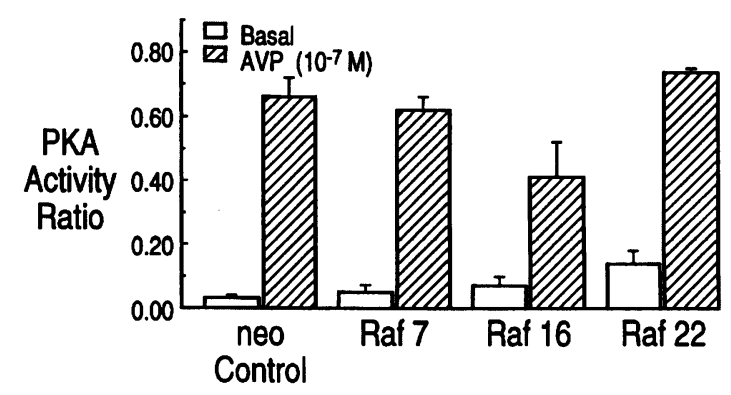

Figure 4. (A) Immunoblot analysis of Raf expression. The transfected clones reveal the BXB Raf protein, which is not seen in the Neo controls. (B) Basal and TPA-stimulated MAPK activity in three BXB Raf clones and Neo control. Clones have a significant increase in basal MAPK activity. ${ }^{*} P<0.05$. (C) AVP-stimulated PKA activity in Raftransfected clones. All of the clones responded with an increase in the PKA ratio to an extent not significantly different from control Neotransfected M-1 cells.

tively active $G_{\alpha s}$ protein with very high basal PKA activity (Wong, R., and T. Berl, unpublished observation). It would appear, therefore, that in M-1 cells these two pathways are not mutually inhibitory, as only an effect of high Ras expression on AVP-stimulated PKA is evident.

The previously mentioned effect of cAMP in inhibiting MAPK has been felt to be mediated by an effect on Raf- 1 (22) that leads to activation of MAPK through the intermediary protein kinase MEK (23). To assess whether Raf is in turn the mediator of the PKA inhibition described in this study, we developed transfected M-1 clones that overexpress this protein. Despite displaying high MAPK in these clones, AVP consistently increased PKA. Such an observation in fact brings into question the inhibitory role of MAPK. The data thus point to distinct Ras-regulated pathways as the critical mediator of the inhibition seen in the current experiments as well as probably in the setting of the aforementioned agonist that activate this pathway via stimulation of PKC. It is now clear that Ras regulates the activation not only of Raf, but also of another serine threonine protein kinases, MEK kinase (24). Finally, a recent report indicates that Ras may interact with phosphatidylinositol3-OH (PI3) kinase as well (25). It is thus possible that Ras inhibits AVP signaling indirectly as a consequence of constitutive regulation of MEK kinase or PI3 kinase. Furthermore, it 
must be noted that findings in a cell culture system cannot be extrapolated to be automatically applicable to an intact tubule.

In summary, our experiments are the first to demonstrate, in cultured mouse collecting duct cell, that overexpressed activated Ras inhibits AVP stimulation of PKA. This inhibition appears to reside at the level of the receptor, since neither forskolinnor cholera toxin-stimulated PKA is altered. Raf transfectants that equally enhance MAPK activity display no such inhibition, suggesting that a parallel Ras-regulated pathway is probably involved. These studies thus define a novel pathway that may well play a role in the inhibition of AVP action associated with a number of hormones and autocoids. The effectors specifically responsible for the process and the mechanisms responsible for the decrease in receptor function are subjects of further investigation.

\section{Acknowledgments}

Ms. Linda Benson provided expert secretarial assistance.

This work was supported by National Institutes of Health grant DK-19928.

\section{References}

1. Breyer, M. D. 1991. Regulation of water and salt transport in collecting duct through calcium dependent signalling mechanisms. Am. J. Physiol. 260:F1 F11.

2. Hebert, R., H. Jacobson, and M. Breyer. 1990. PGE $_{2}$ inhibits AVP-induced water flow in cortical collecting duct by protein kinase C activation. Am. J. Physiol. 259:F318-F325.

3. Nadler, S. P., J. A. Zimpelman, and R. L. Hebert. 1992. Endothelin inhibits vasopressin-stimulated water permeability in rat terminal inner medullary collecting duct. J. Clin. Invest. 90:1458-1466.

4. Snyder, H. M., D. M. Fredin, and M. D. Breyer. 1991. Muscarinic receptor activation inhibits AVP-induced water flow in rabbit cortical collecting ducts. Am. J. Physiol. 260:F929-F936.

5. Breyer, M., H. Jacobson, and Y. Breyer. 1988. Epidermal growth factor inhibits the hydroosmotic effect of vasopressin in the isolated rabbit cortical collecting tubule. J. Clin. Invest. 82:1313-1320.

6. Teitelbaum, I. 1990. cAMP and diacylglycerol: mutually inhibitory second messengers in cultured rat inner medullary collecting tubule cells. J. Clin. Invest. $86: 46-51$.
7. Cobb, M. H., T. G. Boulton, and D. J. Robbins. 1991. Extracellular signalregulated kinases: ERKs in progress. Cell Regul. 2:965-978.

8. Heasley, L. E., S. I. Senkfor, S. Winitz, A. Strasheim, I. Teitelbaum, and T. Berl. 1994. Hormonal regulation of MAP kinase in cultured rat inner medullary collecting tubule cells. Am. J. Physiol. 267:F366-F373.

9. Wu, J., P. Dent, T. Jeliuch, A. Wolfman, M. Weber, and T. Sturgill. 1993. Inhibition of the EGF activated MAP kinase signaling pathway by adenosine 3'5'-monophosphate. Science (Wash. DC). 262:1065-1072.

10. Sevetson, B., X. Kong, and J. Lawrence. 1993. Increasing cAMP attenuates activation of mitogen-activated protein kinase. Proc. Natl. Acad. Sci. USA 90:10305-10309.

11. Graves, L., K. Bornfeldt, E. Raines, B. Potts, S. McDonald, R. Ross, and E. Krebs. 1993. Protein kinase A antagonizes platelet derived growth factor signaling by mitogenic protein kinase in human arterial smooth muscle cells. Proc Natl. Acad. Sci. USA. 90:10300-10304.

12. Stoos, B. A., A. Naray-Fejes Toth, O. Carreteri, S. Ito, and G. G. FejesToth. 1991. Characterization of a mouse cortical collecting duct cell line. Kidney Int. 39:1168-1175.

13. Fejes-Toth, G., and A. Naraj-Fejes-Toth. 1992. Differentiation of renal $\beta$ intercalated cells to $\alpha$ intercalated and principal cells in culture. Proc. Natl. Acad. Sci. USA. 89:5485-5491.

14. Kirschmeier, P. J., G. M. Housey, M. D. Johnson, A. S. Perkins, and I. B. Weinstein. 1988. Construction and characterization of a retroviral vector demonstrating efficient expression of cloned cDNA sequences. DNA. 7:219-225.

5. Markowitz, D., S. Goff, and A. Bank. 1988. A safe packaging cell line for gene transfer: separating viral genes on two different plasmids. J.Virol. 62:1120-1124

16. Heidecker, G., M. Huleihel, J. L. Cleveland, W. Kolch, T. W. Beck, P. Lloyd, T. Pawson, and U. R. Rapp. 1990. Mutational activation of c-Raf-1 and definition of the minimal transforming sequence. Mol. Cell. Biol. 10:2503-2512.

17. Miller, A. D., and G. J. Rosman. 1989. Improved retroviral vectors for gene transfer and expression. Biotechniques. 7:980-990.

18. Teitelbaum, I., A. Strasheim, and T. Berl. 1990. Epidermal growth factorstimulated phosphoinositide hydrolysis in cultured rat inner medullary collecting tubule cells. Regulation by G protein, calcium, and protein kinase C. J. Clin. Invest. 85:1044-1050.

19. Boguski, M., and F. McCormick. 1993. Protein regulating Ras and its relatives. Nature (Lond.). 366:643-653.

20. Cook, S., and F. McCormick. 1994. Ras blooms in sterile ground. Nature (Lond.). 369:361-362.

21. Hall, A. 1994. A biochemical function for Ras-at last. Science (Wash. DC). 264:1413-1414

22. Cook, M. J., and F. McCormick. 1993. Inhibition by cAMP of Rasdependent activation of Raf. Science (Wash. DC). 262:1069-1072.

23. Nakielny, S., P. Cohen, J. Wu, and T. W. Sturgill. 1992. MAP kinase activator from insulin-stimulated skeletal muscle is a protein threonine/tyrosine kinase. EMBO (Eur. Mol. Biol. Org.) J. 11:2123-2129.

24. Lange-Carter, C., and G. L. Johnson. 1994. Ras-dependent growth factor regulator of MEK kinase in PC12 cells. Science (Wash. DC). 265:1458-1461.

25. Rodriguez-Viciana, P., P. H. Warne, R. Dhand, B. Vanhaesebroeck, I.

Gant, M. J. Fry, M. D. Waterfield, and J. Downward. 1994. Phosphatidylinositol3-OH kinase as a direct target of Ras. Nature (Lond.). 370:527-532. 